\title{
1. Introduction: from diversity of interpretations to sustainability of institutions
}

\section{Päivi Eriksson, Ulla Hytti, Katri Komulainen, Tero Montonen and Päivi Siivonen}

Academic entrepreneurship as a concept carries both utopian and dystopian views of entrepreneurship in academia (e.g. Clark, 1998; Slaughter \& Leslie, 1997). Drawing from Ekman (2017, pp. 462-3), we suggest that these utopian and dystopian polarisations prevail 'at the expense of contradictions and grey zones' that we can find in different geographical contexts, changing historical periods, and across diverse academic lives. This book explores those grey zones, extending across and beyond polarised views. Addressing the more complex grey zones provides opportunities to study paradoxes, contradictions, and tensions concerning academic entrepreneurship and explore how these connect with patterns such as acceptance-resistance and oppressionemancipation (cf. Verduijn et al., 2014).

The purpose of this book is to extend the boundaries of research on academic entrepreneurship. This starts with pushing the understanding of entrepreneurship 'as positive economic activity' towards entrepreneurship 'as social change' that can produce various outcomes (Steyaert \& Hjorth, 2008). Entrepreneurship not only concerns economic activity but extends beyond it, and it is not only connected to positive outcomes. By academic entrepreneurship, we refer to all kinds of entrepreneurial activities carried out in academic contexts, including entrepreneurship education, research commercialisation, and the extension of university-industry and university-society relationships more widely. In a nutshell, the book challenges essentialist and polarised views of academic entrepreneurship using diverse theoretical insights and rich empirical data. 


\section{THE UNIVERSITY ECOSYSTEM PERSPECTIVE ON ENTREPRENEURIAL ACTIVITIES}

Entrepreneurship research has a strong tradition of focusing on individual entrepreneurs (Gartner, 1988) as atomistic and isolated socio-economic actors (Drakopoulou Dodd \& Anderson, 2007) or even as 'heroes' (Anderson \& Warren, 2011). In this vein, academic entrepreneurs' motivations and goals (Lam, 2011) have also been studied. This view of entrepreneurship can be criticised for overemphasising the role and agency of individuals and ignoring the institutional and contextual factors at play.

More recently, the focus has shifted towards a more systemic perspective, with research into entrepreneurial ecosystems (Alvedalen \& Boschma, 2017) moving the focus away from individuals and their motivations and capabilities. The systemic view has an emphasis on 'identifying the key components of successful entrepreneurial ecosystems, such as sufficient sources of capital or entrepreneurs creating new ventures in a diverse array of industries' (Roundy, 2016, p. 242). Spigel (2017), for instance, suggests that ecosystems are made up of cultural, social, and material components that provide benefits and resources to entrepreneurs. Furthermore, it is the relationships between the components that form the ecosystem.

Siegel and Wright (2015), however, suggest that 'previous approaches have largely not considered all dimensions of the new entrepreneurial ecosystem, which has broadened out the rationale to reflect the wider social and economic benefits of academic entrepreneurship to the university ecosystem' (p. 585). They criticise the narrow view of academic entrepreneurship as the transfer of scientists' inventions in the natural sciences to patents, licences, and spin-offs and suggest broadening the focus to other stakeholders, including faculty, staff, and students. In this book, we use the term 'university ecosystem' to refer to the narrative context of academic entrepreneurship and to a wide range of inter-related actors and stakeholders that contribute to and benefit from knowledge production in universities. The university ecosystem is a community of professors, researchers, teachers, students, administrators, academic managers, and their stakeholders, all of whom are connected to each other. In the university ecosystem, academics and non-academics may engage in various entrepreneurial activities and processes, such as educating students in entrepreneurial mindsets and supporting researchers in commercialising their research. In this book, we are interested in how these diverse actors engage in entrepreneurial activities in the university ecosystem.

Roundy (2016) argues that current research should pay more attention to the processes through which various actors interpret and analyse activities within entrepreneurial ecosystems and how they understand entrepreneurial activities 
in knowledge ecosystems around universities. Our book deals with the latter focus on universities as knowledge ecosystems that pursue different entrepreneurial activities. The university ecosystem pulls the actors in its environment into the sphere of knowledge production. Knowledge production in the form of research and education is a key activity in the university ecosystem, and the flow of knowledge is the glue that keeps the system together. Roundy (2016) further highlights that what is lacking is an understanding of all ecosystems as socially constructed through cognitive and cultural processes, such as individual and collective sensemaking. He proposes that narratives may serve and be purposefully used as powerful sensemaking devices in complex ecosystems, such as universities. This book is designed to provide narratives that will help its readers to make sense of the movements and nuances of academic entrepreneurship in the context of the university ecosystem.

In this book, we acknowledge that many versions of academic entrepreneurship live within the university ecosystem. While academic entrepreneurship tends to be defined as a techno-economic activity that benefits the entrepreneurs and the university, it may also be about social creativity without predetermined ends (Hjorth \& Holt, 2016) and creation of societal impact beyond economic value (Mars \& Rios-Aguilar, 2010). To emphasise the broader meanings of entrepreneurship, Steyaert and Katz (2004) suggest that entrepreneurship in general can be conceptualised as a societal rather than an economic phenomenon.

This introductory chapter frames the conceptual and empirical terrain of academic entrepreneurship that is discussed in this book and identifies five perspectives to it: (1) higher education policy and administration on the move; (2) entrepreneurial universities claiming their future; (3) the student experience of academic entrepreneurship; (4) academics becoming entrepreneurs; and (5) future movements. Offering these perspectives is not an effort to categorise academic entrepreneurship, but to outline its rich landscape.

Discussing these perspectives in the next sections, we ask, 'How is academic entrepreneurship narrated in this book?' This question helps us to think about academic entrepreneurship as a socially constructed process emerging from the multiple interpretations by different actors in different contexts (Prasad, 2017). This offers the possibility of understanding the movements of academic entrepreneurship within the university ecosystem at the crossroads of social, economic, and political discourses and practices. The introduction closes by offering some questions to stimulate future conversations about research on academic entrepreneurship. 


\section{HIGHER EDUCATION POLICY AND ADMINISTRATION ON THE MOVE}

As the knowledge economy discourse has flourished during the past decades, supranational, national, and local policy narratives have begun to highlight universities as key contributors to societal and economic prosperity. Higher education policy research shows how policymakers have urged universities to transform from 'ivory towers' to 'public institutions' that produce knowledge, innovation, and a skilled workforce for economic needs and how universities have responded to this (Tomlinson \& Holmes, 2017; Wright \& Shore, 2017). Critical policy and administration research in higher education suggests, however, that we should provide more nuanced studies on the construction of these policies and, while analysing the homogenising and dominating discourses, also focus on the diversity of interpretations at the national, regional, and organisational levels.

Although the entrepreneurship discourse used in the supranational policy documents fades out national differences, the cultural context and circumstances affect how academic entrepreneurship is understood and applied in practice (Blenker et al., 2012). Despite the fact that supranational and national policies are constructed as homogenising, countries, regions, and universities may interpret these policies in very different ways (Capano \& Pritoni, 2019). For example, Schulze-Cleven and Olson (2017) show that higher education in the US, Germany, and Norway has undergone processes defined as the strengthening of market principles-self-reliance, rivalry, and decentralised decision-making - in university governance. However, the historical legacies of those countries influence the political dynamics of national transformation, conditioning competition among universities. The US early embrace of tuition financing has shaped the country's recent politics of adaptation, pushing its reforms towards student-oriented and price-based markets. In Germany and Norway, however, quasi-markets have dominated the higher education field, and the focus has been on research output.

Karlsen and Larrea (2019) argue that the discourses on universities tend to rely on the one-size-fits-all approach. Referring to Levin and Greenwood (2016, p. 22), they open up the variety of universities, such as public and private universities, non-profit and for-profit universities, as well as liberal arts, land grant, and flagship universities, which operate in different ways despite being influenced by the same policies. Karlsen and Larrea (2019) point out that in addition to differences between universities, there are differences within universities. Although most universities consist of the same three key groups - administration, students, and faculty - these interact in various ways in different universities (Levin and Greenwood, 2016). 
The authors of this book contribute to critical research on academic entrepreneurship by elaborating on the supranational, national, and university-level discourses, policies, and practices. The chapter by Van Langenhove and Eriksson provides an analysis of how the European knowledge society discourse has constructed the economic and entrepreneurial perspective in higher education from the late 1990 s to present times. They elaborate on the role of the European Union in this process through the cases of the Bologna Process, Lisbon Strategy, and President Macron's initiative of European Universities in the Gothenburg meeting in 2017. These examples show that despite higher education being governed nationally, the 'knowledge Europe' narrative, especially when taken on the agenda of 'policy entrepreneurs', has been influential in paving the way for more entrepreneurially oriented universities across Europe.

In their chapter-based on critical discourse analysis of two British higher education policy documents-Tomlinson, Siivonen, and Laalo show that entrepreneurship and employability are in fact 'two sides of the same coin'. Both emphasise university graduates' economic success and fitness within the framework of academic capitalism. In the UK, however, employability is associated with measures between effective institutional provision and graduates' future outcomes. Entrepreneurship, on the other hand, is described by the authors as a 'leitmotif' and not a central agenda in framing the economic value that English higher education institutions (HEIs) generate. It is not part of the measured market in the way employability is. It may be measured for an institution's own purposes, not for its public image and profile. The chapter provides an example of how supranational policy discourses of entrepreneurship and employability are interpreted in the national UK higher education (HE) policy context.

The chapter by Tuunainen, Kantasalmi, and Laari-Salmela examines the organisational experimentation and decision-making universities engage in when they seek to introduce entrepreneurship education into their activities. A systems-theoretical approach was applied for analysing administrative decision-making in two Finnish universities. The analysis is based on a rich dataset of 19 interviews and 90 documents from 2010 to 2020. The longitudinal data allows the analysis of a temporal dimension in decision-making communication. The chapter highlights differences and similarities in the universities' transformation processes as they seek to advance entrepreneurship alongside science-oriented degree programmes. The chapter shows that universities use flexible and creative steering mechanisms in the face of differing educational content expectations. 


\section{ENTREPRENEURIAL UNIVERSITIES CLAIMING THEIR FUTURES}

The entrepreneurial university concept was introduced more than two decades ago (Clark, 1998; Etzkowitz, 1998) with the aim of strengthening the impact of universities on society (Siegel \& Wright, 2015). Since then, entrepreneurial universities have become an important point of reference for future-oriented higher education policy discussions around the globe. Prior research has contributed to the (ideal) models for the entrepreneurial university and its evolution: what it is and what it does (Etzkowitz, 2014). Yet researchers have also emphasised the endless transition of entrepreneurial universities as an outcome of non-linear innovation models (Etzkowitz \& Leydesdorff, 2000) and of following an iterative, non-linear path influenced by organisational and environmental forces (Stolze, 2021).

Despite the fact that our understanding of the emergence of entrepreneurial activities in universities is limited, many prior contributions have focused on developing a 'single narrative' of the entrepreneurial university and its ecosystem (Pinheiro \& Stensaker, 2014, p. 501). However, as the authors in this book suggest (e.g. MacNeil et al.), more than one understanding of entrepreneurship can coexist in one university, not to mention between different universities. In their study of British universities, Sánchez-Barrioluengo and Benneworth (2019) found their third mission profiles to be very diverse. While the most prestigious older universities focused on research through partnerships with large companies and other organisations, other well-established universities engaged in a broad exchange of knowledge with less specialisation. The newer and less research-oriented universities were involved in consultancy and spin-off creation.

In extant theorising of the entrepreneurial university, the societal and organisational levels have been granted primacy through the emphasis on developing new knowledge of their 'architecture', especially structures, systems, leadership, strategies, and culture (Foss \& Gibson, 2015). Little attention has been paid to individuals and groups who work at universities. In addition to faculty, academic managers are important because as individuals and groups, they are expected to use their decision-making power on entrepreneurial matters in their organisations. We can ask, for instance, how academic managers of universities adopt and comply with entrepreneurship and related discourses (Du Gay, 2004), and how managers negotiate, re-formulate, and resist these, and construct multi-voiced and dilemmatic realities for entrepreneurship in universities (Fournier \& Grey, 1999).

In this book, the authors develop new knowledge from the perspective of university members in contributing to and shaping the entrepreneurial univer- 
sity. Highlighting the individuals and their agency, as well as the possibility of multiple narratives that coexist in and across the universities, opens up the possibility for resistance against a single unified understanding and opens up alternatives for depicting the entrepreneurial university (Berglund et al., 2021; Jones et al., 2020).

Based on a week-long ethnographic field study, in their chapter, MacNeil et al. present four narratives in which the Waterloo University campus is a lonely crowd, an entrepreneurship-producing factory, a welcoming community, and/ or a cult. The authors argue that the ecosystem metanarrative is problematic because it implies pluri-vocality (or polysemy) - that is, a single entrepreneurial context that can be described in numerous different ways-which encourages the employment of monologic narratives about entrepreneurship experiences when they share geography. The chapter opens up opportunities for alternative voices and stories about place and academic entrepreneurship.

The chapter by Montonen et al. presents an analysis of how the interviewed top academic managers make sense of the Third Mission of Finnish universities. Via a composite thematised narrative, the authors detail the interpretive flexibility of the Third Mission metaphor as a boundary-crossing object in use in academic managers' accounts. The analysis also illustrates the complexity of Third Mission as an epistemic object that embodies something not yet known; enriches our understanding of objects that cross the university-society boundary as partially shared, fragmented, and disputed; and shows how these constitute key infrastructure for boundary-crossing activities with multiple stakeholders.

In their chapter, based on various qualitative data, Peura et al. illustrate the complexities of doing insider research in the entrepreneurial university. They discuss ways in which insider researchers engage in identity work to identify themselves and the researched in the data co-creation. Specifically, the process requires negotiating identities by continuously being close to and distancing from academic study participants. Consequently, being an insider is not a fixed but rather a dynamic position related to the study context.

\section{THE STUDENT EXPERIENCE OF ACADEMIC ENTREPRENEURSHIP}

Entrepreneurship education research has been vigorously interested in analysing and discussing what could be termed the 'supply side': institutional policies towards entrepreneurship education, teaching, and learning pedagogy, and mapping of entrepreneurship education teaching programmes (Pittaway \& Cope, 2007). When it comes to the students, the student propensity - what kind of entrepreneurial attitudes or intentions university students have-and whether those can be enhanced via entrepreneurship education (Bae et al., 
2014) has been of interest. Thus, in this domain, the students have been largely understood as the 'objects', not as 'stakeholders' or 'subjects' in universities and in the entrepreneurial ecosystems around them (Lahikainen et al., 2021). Hence, extant research suggests a 'functionalist framing of identity work as something that may be steered towards specific outcomes in entrepreneurship education if the right buttons are pushed with suitable pedagogical methods' (Frederiksen \& Berglund, 2020, p. 288).

This framing of students as carriers of entrepreneurial attitudes reflects an essential view of the self or identity. It covers the ways in which selves evolve and continuously change in each individual's personal history and in different kinds of historical and cultural contexts. Moreover, an essentialist view hides the link between self and narration. Bruner (2004) proposes that we constantly construct and re-construct ourselves to meet the needs of the situations we encounter. Thus, one of the important starting points of this book is to stress the nature of narratives to emerging academic entrepreneurial selves.

However, selves are constructed not so much in 'big stories', but rather within the space of everyday interaction with others, in which narration plays its constitutive role in the formation and navigation of selves (Bamberg, 2011). University as an entrepreneurial ecosystem can, then, be seen as a narrative environment (Gubrium \& Holstein, 2008) or social frames that create the social landscape of action and consciousness of our lives (Goffman, 1974). Frames can be seen as general agreements (or disagreements) that constrain the field of possibilities of agents in a given setting. The notion of frame implies that we use some kind of schemata to set the ground for 'what is going on'. However, the existence of multiple framings means that different university ecosystems can frame academic entrepreneurship and entrepreneurship education in differing ways and that different individuals and groups within universities can frame them in differing ways (Niska, 2020; Tunstall, 2018).

Within ecosystems, persons act within and move between social frames, which could be conceptualised as boundary-crossing (Montonen et al. in this volume). The idea of boundary-crossing emphasises the boundaries that define a particular frame and the notion of crossing, the process one enters (or refuses to enter) in that new frame and its social relationships and groups (Zittoun et al., 2013, p. 276). In this sense, persons are situated within contexts that may facilitate or inhibit their ability to construct and narrate themselves as emerging academic entrepreneurial selves (Baker \& Welter, 2020). This calls for understanding identities-in-context that 'are "filled up" with histories, values, and, other meanings' (Pratt, 2020, p. 888), sensitising us to understanding how students come from different backgrounds and are embedded and socialised in different academic disciplines and cultures contributing to the social frames.

Previously, Siivonen et al. (2020) demonstrated how active members in student entrepreneurship societies participate in constructing a collective and 
coherent identity that is regulated by shared values and a positive state of mind. The student entrepreneurship society - and entrepreneurial activities more broadly - are open to 'everyone', provided that one can and is willing to 'fit in' by adopting an entrepreneurial mindset, assuming self-responsibility, and engaging with positive thinking and forward-looking optimism. In this book, several authors explore university students' experiences of academic entrepreneurship as a new social frame and the ways by which students confer sense on the situation and negotiate their selves or identities as academic and entrepreneurial persons. The new social frames are not, however, neutral. The university as an ecosystem provides multiple and often hierarchical and contradictory social frames within which students confer both the sense of the situation and their selves as actors in these situations.

In her autoethnography chapter, Elkina explores how the discourse of masculine attributes of entrepreneurship makes it difficult to relate oneself to the student entrepreneurship community and contributes to a sense of non-belonging. Elkina and the other authors in this book make visible the ways by which the university as an entrepreneurial ecosystem can contribute to and reproduce masculine, heroic entrepreneurship as something desirable but often veiled into 'gender blindness' by underlining the inclusiveness and openness of the activities to all (Siivonen et al., 2020). For a person becoming and identifying as an entrepreneur, it thus becomes necessary to understand the 'gender subtext' and become 'gender aware' in the process.

Based on a case study, Komulainen and Korhonen show in their chapter how construing oneself as an enterprising self creates new standards for the Homo Academicus and thus may challenge, in many ways, the traditional interpretations of what it means to be an academically educated university student and a future HE graduate in working life. Moreover, while entrepreneurship is claimed to be a career opportunity for all university students, it is conceived differently for different disciplines; it does not treat disciplines or students equally but places them hierarchically based on their profitability and potential economic growth (Laalo et al., 2019). Thus, for the university students, an invitation to construe oneself as an enterprising self means movement between academic and entrepreneurship frames and boundary-crossing.

The authors in this book reveal that narrative acts of self-making are guided by implicit cultural models of what selfhood should be, might be, and, of course, should not be. Markus and Nurius (1986) conceptualise different selves with the concept of possible selves. They represent individuals' ideas of what they might become, what they would like to become, and what they are afraid of becoming and thus provide a conceptual link between cognition, motivation, and affects. In addition, possible selves provide an evaluative and interpretive context for the current view of self. In their chapter, Kasanen and Räty utilise the concept of expected ability self, which refers to students' 
expectations of those abilities they anticipate that working life will require of them. Based on a large-scale survey, they find a somewhat paradoxical state of affairs. When attributed as part of an individual's existing abilities, entrepreneurial skills are associated with an optimistic perception of one's working life horizon, whereas when attributed as expected abilities, the very same skills tend to be associated with a pessimistic perception. Overall, the normative representation of abilities - reflecting the demands of present-day work life echoed by universities - is associated with students' ability selves and is therefore prone to tensions.

Introducing entrepreneurship education across the university campus with the aim of giving all students the possibility to access it irrespective of their discipline or faculty has become 'the new ideal', which is taken for granted and self-evidently expected to add value to mainstream university education (Hytti, 2018). However, as the authors in this book suggest, in an academic context, entrepreneurship is considered a rather restricted category into which only a few specific individuals have access (cf. Berglund \& Johansson, 2007).

\section{ACADEMICS BECOMING ENTREPRENEURS}

In the past decade, interest in the commercialisation activities of universities has expanded rapidly. In the current research, academic entrepreneurs stand out as driving identity models for future academics, in which entrepreneurship is a channel for transformation and empowerment at the societal and individual levels (Farny et al., 2016). Much of the previous research has been either descriptive or phenomenon and/or data driven, and not always engaged in theoretical and methodological discussions. Topic-wise, the research has mostly focused on academic entrepreneurship as human and social capital with heterogeneous objectives and demographic characteristics (Hmieleski \& Powell, 2018). Furthermore, a division has been made between academic entrepreneurs who engage in the well-defined activities guided by the technology transfer offices in universities and entrepreneurial academics who implement broader and less formal dissemination of knowledge (Miller et al., 2018). An emerging trend in research is to study university students as academic entrepreneurial agents (Hmieleski \& Powell, 2018).

Much of the prior research has focused on the motivations to establish academic spin-offs (Galati et al., 2020), the personal interests of scientists that might lead to starting companies (Blair \& Shaver, 2020), and the tension between academic identities and entrepreneur identities (Shi et al., 2020). Much of the research has an implicit starting point of entrepreneurs as 'great persons' (Boltanski \& Chiapello, 2005), which may lead to a narrow and restrictive version of entrepreneurship that many academics find difficult to relate to (Berglund \& Johansson, 2007). Also, much of the prior research 
neglects the agency and introspection of scientists engaging in entrepreneurship (Bousfiha, 2020).

While the academic entrepreneurship option may be widely available, and universities offer different support measures for it, entrepreneurial processes are not equally open to everybody or inclusive in other ways (Montonen et al., 2019; Elkina in this volume). Consequently, there is room for more studies on how the diverse journeys of academic entrepreneurs unfold; how the stories of these entrepreneurs construct identities, tensions, and solutions; and whose understandings are privileged in and by these stories (Pilegaard et al., 2010; Moilanen et al., in this volume). We also need a better understanding of the gendering and social sustainability of entrepreneurial journeys. For instance, how academic entrepreneurs make these journeys meaningful for themselves (Suopajärvi, Ylijoki, \& Salminen Karlsson in this volume; Sengupta in this volume).

In this book, the chapter by Moilanen et al. focuses on the meanings of academic entrepreneurship in the context of a start-up accelerator in which university scientists participated. Constructing an alternative story to the Finnish start-up world, in contrast to the narratives by other researchers in the field, the authors illustrate how scientists and their mentors co-constructed the sense of (lacking) credibility of scientists in the start-up world. In contrast to prior research with a focus on start-up culture, this story focuses on the micro-level social process of critical sensemaking unfolding over time.

Based on interview data, the chapter by Suopajärvi et al. elaborates on women's experiences of becoming and being academic entrepreneurs in the research area of health technology in Finland and Sweden. They follow feminist critics of entrepreneurship studies, which focus mainly on questioning how women could fit better into the masculine idea of entrepreneurship and thus how women could become more risk-taking and self-centred. Their results show that academic entrepreneurship is a social matter in which the desire to benefit others, a wish to work in a non-hierarchical environment, and social relations in the private and public spheres of life matter. They further show how entrepreneurial journeys are quite versatile and depend on women's life situations, for example, but also on the academic structures that appear more rigid in Finland than in Sweden.

In his chapter, Sengupta shows how an academic context encourages and supports two students in starting up a social enterprise with a strong social and low economic orientation. The case describes how the start-up's inception and journey unfolded in the early phases. It shows that social entrepreneurs, mobilised by their academic context, take the opportunity to develop an attachment and a commitment to planning and creating a social enterprise for addressing community issues through localised solutions and engagement. He introduces 
the concept of a 'social academic enterprise' and a new direction for future research.

Many chapters in this book introduce data and methods that have novelty in academic entrepreneurship research. In addition, Hirvonen and Van Langenhove provide a discussion on social psychological positioning theory and the respective method that can be used to study academic entrepreneurship at the micro level. At the very end of the book, the editors of the first four books in the New Movements in Entrepreneurship book series by Edward Elgar, Daniel Hjorth and Chris Steyaert present their analysis of the chapters in this book and of the new and future movements in academic entrepreneurship.

\section{CONCLUSION}

According to Spigel (2017), ecosystems represent a conceptual umbrella that encompasses a variety of perspectives rather than a coherent theory about communities of entrepreneurs. Spigel suggests that to be an effective theoretical construct, the ecosystem theory should identify cultural, social, and material attributes that constitute the ecosystem. Instead of exploring the foundational attributes of ecosystems and how ecosystems affect the entrepreneurship process, our book methodologically approaches academic entrepreneurship by highlighting the practices and processes through which various actors interpret and analyse activities in entrepreneurial ecosystems.

The methodological aim of this book is to capture both the diversity of the meaning of academic entrepreneurship and the practices through which these meanings are produced in the university ecosystem. In doing so, the book encourages researchers to extend research from individuals' sensemaking and stories to the interactional, cultural, and institutional fields of narrative production. In other words, into the ecosystems of interpretative practices (e.g. Holstein \& Gubrium, 2011). Moreover, the book encourages researchers to focus on interpretative practices as relational: how people representing certain positions in the ecosystem come to be and how they come to know the (entrepreneurial) world interactively through exchanges, conversations, joint acts, and co-ordinations (Fletcher, 2007; Steyaert \& Bouwen, 1997).

Fields of interpretive practices are understood as important in academic entrepreneurship, calling for further analyses of identity work in different contexts (e.g. discipline, university history, but also place/region). Place may be important for understanding the networks and other resources available — or lack thereof-in fostering entrepreneurship. More attention to interpretative practices would provide richer and more contextualised understanding of academic entrepreneurship and enable more focus on processes and social interactions, continuity, and change (Hmieleski \& Powell, 2018). 
However, interpretative practices are not neutral. The contributions in this book put forward gendering as an important issue for women aspiring to entrepreneurship in academia. While women's issues are important, future research on gender should not be limited to women but also include men or focus exclusively on questioning the masculinities academic entrepreneurship calls for. For example, technology transfer has been identified as a masculine and male-dominated area, which begs the question: which men and what kind of masculinities? In this way, we could better understand how male academicsfor instance, in the humanities - are not included in this masculine domain.

Entrepreneurship education as a space for identity work (Frederiksen \& Berglund, 2020) has been raised as important, but future research could approach this more from the intersectionality perspective, including understanding of gender, race, ethnicity, and class. Research on academic entrepreneurship could benefit from understanding the different visible or invisible barriers or boundaries that exist for the 'universal right to entrepreneurship' that is currently used as a mantra in academic entrepreneurship. Overall, critical analyses are needed to explore how individuals and different social groups in terms of gender, age, ethnicity, and class, and their intersections (Berglund et al., 2017), position themselves to entrepreneurial identities and transform themselves towards, or resist, becoming academic entrepreneurial agents.

Prior research deals with the propensity of individuals and groups in academic entrepreneurship and their ability to envision entrepreneurship. However, future research could pay much more attention to the forms and practices of resistance to question taken-for-granted truths about embracing the 'enterprising self'. For instance, it would be interesting to learn about the results from pedagogical approaches where this questioning is mobilised (Berglund \& Verduijn, 2018). Discursively, entrepreneurship and academia are often positioned as counter-forces, in which case the talk around academic entrepreneurship easily becomes ideological — in favour of or against it. The problem is that ideology easily conceals movements around everyday practices in universities, which we have studied in this book.

\section{REFERENCES}

Alvedalen, J., \& Boschma, R. (2017). A critical review of entrepreneurial ecosystems research: Towards a future research agenda. European Planning Studies, 25(6), 887-903.

Anderson, A.R., \& Warren, L. (2011). The entrepreneur as hero and jester: Enacting the entrepreneurial discourse. International Small Business Journal, 29(6), 589-609.

Bae, T.J., Qian, S., Miao, C., \& Fiet, J.O. (2014). The relationship between entrepreneurship education and entrepreneurial intentions: A meta-analytic review. Entrepreneurship Theory and Practice, 38(2), 217-54. 
Baker, T., \& Welter, F. (2020). Contextualizing entrepreneurship theory. Routledge Studies in Entrepreneurship. New York \& London: Routledge.

Bamberg, M. (2011). Who am I? Narration and its contribution to self and identity. Theory \& Psychology, 21(1), 3-24.

Berglund, K., \& Johansson, A.W. (2007). Constructions of entrepreneurship: A discourse analysis of academic publications. Journal of Enterprising Communities: People and Places in the Global Economy, 1(1), 77-102.

Berglund, K., \& Verduijn, K. (2018). Revitalizing entrepreneurship education: Adopting a critical approach in the classroom. New York: Routledge.

Berglund, K., Lindgren, M., \& Packendorff, J. (2017). Responsibilising the next generation: Fostering the enterprising self through de-mobilising gender. Organization, 24(6), 892-915.

Berglund, K., Alexandersson, A., Jogmark, M., \& Tillmar, M. (2021). An alternative entrepreneurial university? In U. Hytti (ed.), A research agenda for the entrepreneurial university (pp. 7-28). Cheltenham, UK and Northampton, MA, USA: Edward Elgar Publishing.

Blair, C.A., \& Shaver, K.G. (2020). Of horses and jockeys: Perceptions by academic entrepreneurs. Entrepreneurship Research Journal, 10(2), 1-21.

Blenker, P., Hedeboe Frederiksen, S., Korsgaard, S., Muller, S., Neergaard, H., \& Thrane, C. (2012). Entrepreneurship as everyday practice: Towards a personalized pedagogy of enterprise education. Industry and Higher Education, 26(6), 417-30. doi: 10.5367/ihe.2012.0126

Boltanski, L., \& Chiapello, E. (2005). The new spirit of capitalism. International Journal of Politics, Culture, and Society, 18, 161-88.

Bousfiha, M. (2020). The lived experience of academic entrepreneurship: The interplay between practice, identity, and context. Doctoral thesis, series no. 4773. Chalmers University of Technology. https://research.chalmers.se/publication/516689/file/ 516689_Fulltext.pdf

Bruner, J. (2004). The narrative creation of self. In L.E. Angus \& J. McLeod (eds), The handbook of narrative and psychotherapy: Practice, theory, and research (pp. 3-14). Thousand Oaks, CA: SAGE.

Capano, G., \& Pritoni, A. (2019). Varieties of hybrid systemic governance in European higher education. Higher Education Quarterly, 73(1), 10-28.

Clark, B.R. (1998). Creating entrepreneurial universities: Organizational pathways of transformation. Issues in Higher Education. Oxford: IAU Press/Bergamon.

Drakopoulou Dodd, S., \& Anderson, A.R. (2007). Mumpsimus and the mything of the individualistic entrepreneur. International Small Business Journal, 25(4), 341-60.

Du Gay, P. (2004). Against 'Enterprise' (but not against 'enterprise', for that would make no sense). Organization, 11(1), 37-57.

Ekman, S. (2017). A history of vocational ethics and professional identity: How organization scholars navigate academic value spheres. Human Relations, 70(4), 461-87.

Etzkowitz, H. (1998). The norms of entrepreneurial science: Cognitive effects of the new university-industry linkages. Research Policy, 27(8), 823-33.

Etzkowitz, H. (2014). The entrepreneurial university wave: From ivory tower to global economic engine. Industry and Higher Education, 28(4), 223-32.

Etzkowitz, H., \& Leydesdorff, L. (2000). The dynamics of innovation: From national systems and 'Mode 2' to a triple helix of university-industry-government relations. Research Policy, 29(2), 109-23.

Farny, S., Frederiksen, S.H., Hannibal, M., \& Jones, S. (2016). A CULTure of entrepreneurship education. Entrepreneurship \& Regional Development, 28(7-8), 514-35. 
Fletcher, D. (2007). 'Toy Story': The narrative world of entrepreneurship and the creation of interpretive communities. Journal of Business Venturing, 22(5), 649-72.

Foss, L., \& Gibson, D.V. (eds) (2015). The entrepreneurial university: Context and institutional change. New York: Routledge.

Fournier, V., \& Grey, C. (1999). Too much, too little and too often: A critique of du Gay's analysis of enterprise. Organization, 6(1), 107-28.

Frederiksen, S.H., \& Berglund, K. (2020). Identity work in entrepreneurship education: Activating, scripting, and resisting the entrepreneurial self. International Small Business Journal, 38(4), 271-92.

Galati, F., Bigliardi, B., Passaro, R., \& Quinto, I. (2020). Why do academics become entrepreneurs? How do their motivations evolve? Results from an empirical study. International Journal of Entrepreneurial Behavior \& Research, 26(7), 1477-503.

Gartner, W.B. (1988). 'Who is an entrepreneur?' is the wrong question. American Journal of Small Business, 12(4), 11-32.

Goffman, E. (1974). Frame analysis: An essay on the organization of experience. Boston, MA: Northeastern University Press.

Gubrium, J.F., \& Holstein, J.A. (2008). Narrative ethnography. In S.N. Hesse-Biber \& P. Leavy (eds), Handbook of emergent methods (pp. 241-64). New York: The Guilford Press.

Hjorth, D., \& Holt, R. (2016). It's entrepreneurship, not enterprise: Ai Weiwei as entrepreneur. Journal of Business Venturing Insights, 5, 50-4.

Hmieleski, K.M., \& Powell, E.E. (2018). The psychological foundations of university science commercialization: A review of the literature and directions for future research. Academy of Management Perspectives, 32(1), 43-77.

Holstein, J.A., \& Gubrium, J.F. (2011). The constructionist analytics of interpretive practice. In N.K. Denzin \& Y.S. Lincoln (eds), The Sage handbook of qualitative research (pp. 341-58). Thousand Oaks, CA: SAGE.

Hytti, U. (2018). Critical entrepreneurship education: A form of resistance to McEducation? In K. Berglund \& K. Verduijn (eds), Revitalizing entrepreneurship education: Adopting a critical approach in the classroom (pp. 228-34). New York: Routledge.

Jones, D.R., Visser, M., Stokes, P., Örtenblad, A., Deem, R., Rodgers, P., \& Tarba, S.Y. (2020). The performative university: 'Targets', 'terror' and 'taking back control' in academia. Management Learning, 51(4), 363-77.

Karlsen, J., \& Larrea, M. (2019). Does a responsible university need a third mission? In M.P. Sørensen, L. Geschwind, J. Kekäle, \& R. Pinheiro (eds), The responsible university. Exploring the Nordic context and beyond (pp. 173-99). Cham, Switzerland: Palgrave Macmillan.

Laalo, H., Kinnari, H., \& Silvennoinen, H. (2019). Setting new standards for homo academicus: Entrepreneurial university graduates on the EU agenda. European Education, 51(2), 93-110.

Lahikainen, K., Peltonen, K., Hietanen, L., \& Oikkonen, E. (2021). Calling for student engagement in an entrepreneurial university. In U. Hytti (ed.), A research agenda for the entrepreneurial university (pp. 129-42). Cheltenham, UK and Northampton, MA, USA: Edward Elgar Publishing.

Lam, A. (2011). What motivates academic scientists to engage in research commercialization: 'Gold', 'ribbon' or 'puzzle'? Research Policy, 40(10), 1354-68.

Levin, M., \& Greenwood, D.J. (2016). Creating a new public university and reviving democracy: Action research in higher education (Vol. 2). New York \& Oxford: Berghahn Books. 
Markus, H., \& Nurius, P. (1986). Possible selves. American Psychologist, 41(9), 954-69.

Mars, M.M., \& Rios-Aguilar, C. (2010). Academic entrepreneurship (re)defined: Significance and implications for the scholarship of higher education. Higher Education, 59(4), 441-60.

Miller, K., Alexander, A., Cunningham, J.A., \& Albats, E. (2018). Entrepreneurial academics and academic entrepreneurs: A systematic literature review. International Journal of Technology Management, 77(1-3), 9-37.

Montonen, T., Moilanen, J., \& Eriksson, P. (2019). Where does it lead to? Nowhere! Problematic sensemaking concerning commercialization. International Journal of Human Resources Development and Management, 19(1), 62-74.

Niska, M. (2020). Challenging interest alignment: Frame analytic perspective on entrepreneurship education in higher education context. European Educational Research Journal. https://doi.org/10.1177/1474904120909571

Pilegaard, M., Moroz, P.W., \& Neergaard, H. (2010). An auto-ethnographic perspective on academic entrepreneurship: Implications for research in the social sciences and humanities. Academy of Management Perspectives, 24(1), 46-61.

Pinheiro, R., \& Stensaker, B. (2014). Designing the entrepreneurial university: The interpretation of a global idea. Public Organization Review, 14(4), 497-516.

Pittaway, L., \& Cope, J. (2007). Entrepreneurship education: A systematic review of the evidence. International Small Business Journal, 25(5), 479-510.

Prasad, P. (2017). Crafting qualitative research: Beyond positivist traditions. New York: Taylor \& Francis.

Pratt, M.G. (2020). Identity saves the world?: Musings on where identity research has been and where it might go. In A.D. Brown (ed.), The Oxford handbook of identities in organizations (pp. 880-95). Oxford: Oxford University Press. https://doi.org/10 $.1093 /$ oxfordhb/9780198827115.013.17

Roundy, P.T. (2016). Start-up community narratives: The discursive construction of entrepreneurial ecosystems. The Journal of Entrepreneurship, 25(2), 232-48.

Sánchez-Barrioluengo, M., \& Benneworth, P. (2019). Is the entrepreneurial university also regionally engaged? Analysing the influence of university's structural configuration on third mission performance. Technological Forecasting and Social Change, 141, 206-18.

Schulze-Cleven, T., \& Olson, J.R. (2017). Worlds of higher education transformed: Toward varieties of academic capitalism. Higher Education, 73, 813-31. doi: 10.1007/s10734-017-0123-3

Shi, Y., Zou, B., \& Santos, R.S. (2020). Dr. Jekyll and Mr. Hyde: How do academic entrepreneurs deal with identity conflict? Review of Managerial Science. https://doi .org/10.1007

Siegel, D.S., \& Wright, M. (2015). Academic entrepreneurship: Time for a rethink? British Journal of Management, 26(4), 582-95.

Siivonen, P., Peura, K., Hytti, U., Kasanen, K., \& Komulainen, K. (2020). The construction and regulation of collective entrepreneurial identity in student entrepreneurship societies. International Journal of Entrepreneurial Behavior \& Research, 26(3), 521-38.

Slaughter, S., \& Leslie, L.L. (1997). Academic capitalism: Politics, policies, and the entrepreneurial university. Baltimore, MD: Johns Hopkins University Press.

Spigel, B. (2017). The relational organization of entrepreneurial ecosystems. Entrepreneurship Theory and Practice, 41(1), 49-72. 
Steyaert, C., \& Bouwen, R. (1997). Telling stories of entrepreneurship: Towards a narrative-contextual epistemology for entrepreneurial studies. In R. Donckels \& A. Miettinen (eds), Entrepreneurship and SME research: On its way to the next millennium (pp. 47-62). London \& New York: Routledge.

Steyaert, C., \& Hjorth, D. (eds) (2008). Entrepreneurship as social change: A third new movements in entrepreneurship book (Vol. 3). Cheltenham, UK and Northampton, MA, USA: Edward Elgar Publishing.

Steyaert, C., \& Katz, J. (2004). Reclaiming the space of entrepreneurship in society: Geographical, discursive, and social dimensions. Entrepreneurship \& Regional Development, 16(3), 179-96.

Stolze, A. (2021). A meta-ethnography on HEIs' transformation into more entrepreneurial institutions: Towards an action-framework proposition. Industry and Higher Education, 35(1), 14-27.

Tomlinson, M., \& Holmes, L. (eds) (2017). Graduate employability in context: Theory, research and debate. London: Palgrave Macmillan.

Tunstall, R. (2018). Education or exploitation? Reflecting on the entrepreneurial university and the role of the entrepreneurship educator. In K. Berglund \& K. Verduijn (eds), Revitalizing entrepreneurship education: Adopting a critical approach in the classroom (pp. 25-40). New York: Routledge.

Verduijn, K., Dey, P., Tedmanson, D., \& Essers, C. (2014). Emancipation and/or oppression? Conceptualizing dimensions of criticality in entrepreneurship studies. International Journal of Entrepreneurial Behavior \& Research, 20(2), 98-107.

Wright, S., \& Shore, C. (eds) (2017). Death of the public university? Uncertain futures for higher education in the knowledge economy. New York: Berghahn.

Zittoun, T., Valsiner, J., Gonçalves, M.M., Salgado, J., Vedeler, D., \& Ferring, D. (2013). Human development in the life course: Melodies of living. Cambridge: Cambridge University Press. 